\title{
Control and Automation: Insmoaf (Integrated Smart Modern Agriculture and Fisheries) on The Greenhouse Model
}

\section{(Kontrol dan Otomatisasi: Insmoaf (Integrated Smart Modern Agriculture and Fisheries) pada Model Rumah Kaca)}

\author{
Ridwan Siskandar ${ }^{\star *}$, Sesar Husen Santosa ${ }^{2}$, Wiyoto $^{3}$, Billi Rifa Kusumah ${ }^{4}$, Agung Prayudha Hidayat $^{2}$
}

(Received April 2021/Accepted January 2022)

\begin{abstract}
A greenhouse is an agricultural management system that has shown the efficiency of food production. This system is an effective alternative to ensure maximum production results. Agriculture with greenhouse technology can create the desired environmental/climatic conditions. The rapid development of technology and science has led to the birth of communication between devices using loT and Al. This technology can be applied to greenhouses in agriculture and fisheries. Research on greenhouse and microcontroller-based automation systems has been carried out, and it is interesting to be developed. Researchers make a more efficient system and can increase the quality and quantity of production. The measurement data of both modes are monitored using the web. The greenhouse prototype is supported by DHT22, DS18B20, a fan to control the greenhouse cooler, RFID as the key access to the greenhouse. DHT22 \& DS18B20 sensor readings in the prototype greenhouse use an Al system with the fuzzy method. IOT and Al have been successfully implemented in models of rice fields, hydroponic farming, and fisheries using automatic modes of RTC devices and sensors. The fuzzy approach method is used to find the optimum temperature and humidity values. The fuzzy approach was successfully carried out until the temperature and humidity conditions were "ideal," "high," and "very high." This condition provides information to the microcontroller to activate which fan should turn on. In manual mode, the smartphone application controls the system properly.
\end{abstract}

Keywords: artificial intelegent, control and automation, fuzzy logic, greenhouse, loT

\section{ABSTRAK}

Rumah kaca merupakan salah satu sistem pengelolaan pertanian yang telah menunjukkan efisiensi produksi pangan. Sistem ini merupakan alternatif yang efektif untuk memastikan hasil produksi yang maksimal. Pertanian dengan teknologi rumah kaca dapat menciptakan kondisi lingkungan (iklim) yang diinginkan. Pesatnya perkembangan teknologi dan ilmu pengetahuan telah melahirkan komunikasi antarperangkat yang menggunakan loT dan Al. Teknologi ini dapat diterapkan pada rumah kaca di bidang pertanian dan perikanan. Sistem otomasi berbasis rumah kaca dan mikrokontroler telah banyak diteliti dan menarik untuk dikembangkan. Peneliti membuat sistem yang lebih efisien dan dapat meningkatkan kualitas dan kuantitas produksi. Data pengukuran kedua mode dipantau menggunakan web. Prototipe rumah kaca ini didukung oleh DHT22, DS18B20, kipas untuk mengendalikan pendingin rumah kaca, dan RFID sebagai kunci akses ke rumah kaca. Pembacaan sensor DHT22 \& DS18B20 pada prototipe rumah kaca menggunakan sistem Al dengan metode fuzzy. IoT dan Al telah berhasil diimplementasikan pada model persawahan, pertanian hidroponik, dan perikanan menggunakan mode otomatis perangkat dan sensor RTC. Metode pendekatan fuzzy digunakan untuk mencari nilai suhu dan kelembapan yang optimal. Pendekatan fuzzy berhasil dilakukan hingga kondisi suhu dan kelembapan "ideal," "tinggi," dan "sangat tinggi." Kondisi ini memberikan informasi kepada mikrokontroler untuk mengaktifkan kipas mana yang harus dihidupkan. Dalam mode manual, aplikasi smartphone mengendalikan ontrol sistem dengan baik.

Kata kunci: kecerdasan buatan, kontrol dan otomasi, logika fuzzy, rumah kaca, loT

1 Study Program of Computer Engineering, College of Vocational Studies, IPB University, IPB Cilibende Campus, Bogor 16128

2 Study Program of Industrial Management College of Vocational Studies, IPB University, IPB University, IPB Cilibende Campus, Bogor 16128

3 Study Program of Production Technology and Management of Aquaculture, College of Vocational Studies, IPB University, IPB Cilibende Campus, Bogor 16128

4 Study Program of Fishing Technology, Faculty of Marine and Fisheries Technology, Nahdlatul Ulama University of Cirebon, Cirebon 45111

* Coressponden Author:

E-mail: ridwansiskandar@apps.ipb.ac.id

\section{INTRODUCTION}

Advances in information technology and embedded systems in the digitalization era are increasingly leading to studies of control systems, automation, loT, and artificial intelligence. Research in this field, especially the topic of greenhouse in agriculture and fisheries, automation of hydroponic agriculture, automatic watering of rice fields, feeding of fish based on microcontrollers, is exciting to review, as was done by previous researchers (Cobantoro et al. 2019; Syah et al. 2018; Putri et al. 2019; Sutiawan et al. 2020; 
Sutikno and Khotib 2019; Marzuki and Wicaksono 2019; Rahmawati 2019; Sujadi and Nurhidayat 2019; Wulansari and Setyawati 2019; Saraswathi et al. 2011; Meili and Yankang, n.d.; Sung et al. 2017; Pitakphongmetha et al. 2016; Miranda et al. 2019; Siskandar and Kusumah 2019).

Greenhouse farming is an agricultural management system that has shown efficiency in intensifying food production. This system is a safe and viable alternative to ensuring a food supply, one of the most significant challenges facing humanity in the 21 st century (AznarSánchez et al. 2020). Technology has been able to meet the challenges associated with greenhouse farming in overcoming its limitations, correcting adverse effects, and ensuring the system's sustainability (Ferentinos et al. 2015; Meili and Yankang, n.d.; Lamprinos et al. 2015).

The rapid development of technology and science has led to the birth of the 4.0 industrial revolution, which prioritizes communication between devices using loT and $\mathrm{Al}$. IoT is one of the main elements in the development of this revolution. IoT utilization in agriculture can be applied to greenhouse technology (Kusuma et al. 2019; Sujadi and Nurhidayat 2019; Saraswathi et al. 2011). A greenhouse is a building that creates suitable environmental conditions for plant growth and maintenance. In his research, Sujadi and Nurhidayat (2019) explained that the application of IoT in greenhouse technology can monitor temperature, humidity, soil moisture, watering, and fertilizing plants automatically, in real-time, and can control plants remotely. $\mathrm{Al}$ is a simulation of human intelligence carried out by machines and programmed by humans. Machines must learn to reason and self-correct as needed over time (Benyezza et al. 2018; Pourjavad and Shahin 2018). Agriculture with greenhouse technology can create the desired environmental (climatic) conditions. With this technology, plant maintenance will certainly avoid unfavorable conditions, such as too low temperature and high rainfall. One of the cultivation techniques applied in greenhouse technology is agricultural cultivation (rice field and hydroponic models) and aquaculture.

Cultivation is a planned activity to maintain biological resources carried out on land to take advantage of harvest results. Fishery cultivation is an effort to maintain and breed fish or other aquatic organisms. The success of freshwater fish farming is primarily determined by the environment, namely temperature, $\mathrm{pH}$, and oxygen. Therefore, environmental quality must always be a concern so that freshwater fish farming can be optimal. Apart from environmental conditions, the feed factor is also an essential factor in the success of fish farming, so the feeding schedule must be considered (Humaerah 2013; Boonnam et al. 2020; Rahayu et al. 2018; Borstel et al. 2013; Sung et al. 2017; Mccoy et al. 2017; Siregar and Ginting 2017; Miranda et al. 2019; Meijide et al. 2016; Kusuma et al. 2019; Benyezza et al. 2018; Siskandar and Kusumah 2019).
According to BPS data, the rapid population growth rate of $1.94 \%$ per year (more than 237 million people in 2010) has resulted in an increasing need for rice. Meanwhile, the production growth is not proportional to the demand, even slopes. Moreover, high population growth rates also affect land requirements for nonagricultural purposes such as housing, shopping centers, industry, or other public facilities such as elevated roads, toll roads, etc. As a result, the conversion of agricultural land to non-agricultural land has become increasingly difficult to control (Humaerah 2013).

Meili and Yankang (n.d.) designed an automatic control system based on temperature, humidity, and light intensity of agricultural greenhouses. This system's advantages are that the system is quite simple in operation, low cost, and high precision. This system's weakness is that the DHT11 sensor only has a humidity range of $20-80 \%$ with an accuracy of $5 \%$, so the humidity measurement range is not adequate; the monitoring system cannot be done remotely. Lamprinos et al. (2015) in his paper presents the features of implementing a wireless network-based greenhouse monitoring system. The system consists of various sensor nodes that collect environmental condition data and send it to a remote database. The advantage of this system is that it can explore the level of heterogeneity in microclimate conditions in the greenhouse environment; farmers can monitor greenhouse conditions through the web. This system's disadvantages are that the system is only applied to one agricultural model (tomato cultivation); farmers cannot control the system remotely.

Chaudhary et al. 2011 in his paper presents that technological developments in wireless sensor networks allow it to be used in monitoring and controlling greenhouse parameters in precision agriculture. The advantages of this system are: utilizing greenhouse technology as the best solution to overcome weather prediction problems that are unpredictable by farmers. On the other hand, the weaknesses of this system are: the system cannot control the situation if the four parameters do not meet the wishes of the farmers; monitoring parameter data has not used the intelligence system method.

Based on the above background, we took a study entitled "Control and Automation: Insmoaf (Integrated Smart Modern Agriculture and Fisheries) on The Greenhouse Model." The purpose of this study is to develop a system that can facilitate the work of farmers in time and energy efficiency to improve the quality and quantity of agricultural production (paddy field and hydroponic models) and aquaculture in greenhouses. The innovation and novelty of the inSmoAf system are: the system is applied to greenhouse technology which is integrated with agriculture and fisheries models. The system uses two modes in each prototype model: automatic mode and manual mode (control using a smartphone). Data from both modes of work measurement can be monitored using the web. The 
greenhouse prototype is supported by temperature sensors (DHT22 and DS18B20) and humidity (DHT22) that have a better measurement range than DHT11, namely $0-100 \%$ with an error of $2-5 \%$ ), hexos fan to control greenhouse coolers, RFID as access keys to enter the greenhouse. The temperature and humidity reading in the prototype greenhouse uses an Al system with a fuzzy method. The aim is to get the right temperature and humidity values to support improving the quality and quantity of agricultural and fishery production products.

\section{RESEARCH METHOD}

\section{General}

This article describes the experimental research conducted at the Hardware Laboratory, Vocational School of IPB University, from August to December 2020. The materials and tools used in the research included materials and tools for assembling prototype models of greenhouses, materials, and tools for prototyping rice fields models, materials, and tools. For building prototype models of hydroponic models and materials and tools for making prototype models of fish ponds.

\section{InSmoAf System Design and Evaluation on The Greenhouse Model}

We developed inSmoAf in the greenhouse model into three models: rice field farming, hydroponic farming, and fish ponds. The model was designed in two modes, namely automatic and manual. In principle, the systems in each model were integrated. The automatic mode function of each model was

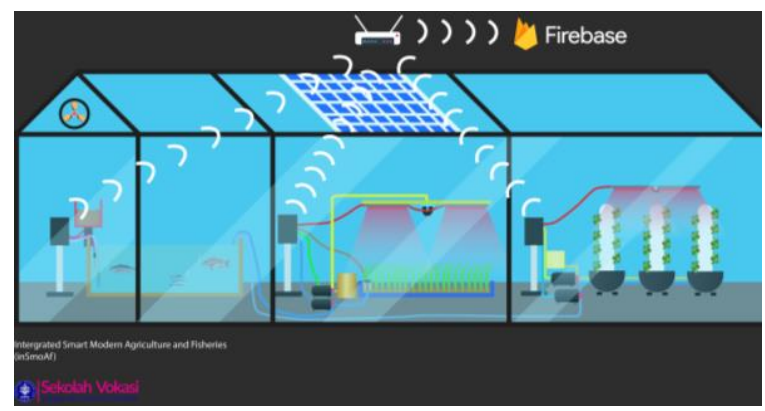

(a)

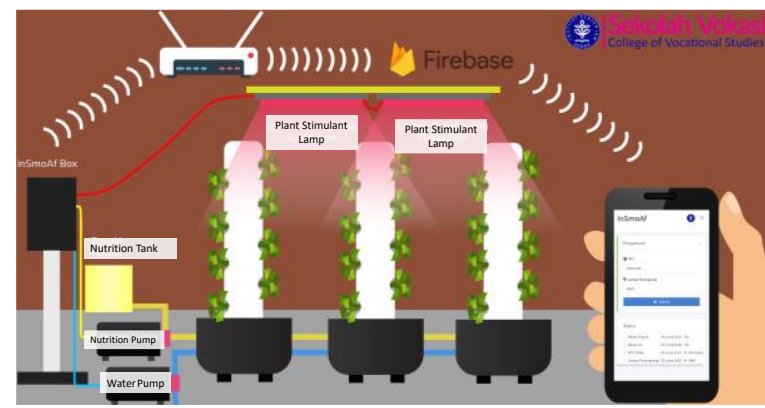

(c) determined from the sensor readings and the predetermined timing conditions. Meanwhile, the manual mode worked when the automatic mode was not activated. The readings made by temperature \& humidity sensors on the prototype model greenhouse used an Al system with a fuzzy method to get the correct value to support the increase in the quality and quantity of cultivation products. From the description above, "Control and Automation: inSmoAf on The Greenhouse Model" updates greenhouse technology in integrated agriculture. We also evaluated a greenhouse technology model using use case analysis (El-madbouly and Hameed 2017; Nasution et al. 2020; Manríquez-Altamirano et al. 2020; Sujadi and Nurhidayat 2019; Meili and Yankang, n.d.; Balaine et al. 2019; Lamprinos et al. 2015; Benyezza et al. 2018; Boonnam et al. 2020; Rahayu et al. 2018; Chaudhary et al. 2011). The general in SmoAf on the greenhouse model solution design is shown in Figure 1.

\section{InSmoAf Mechanism Design}

Figure 2 shows the overall diagram of the inSmoAf system, which is easier to understand. This research was developed to help farmers remotely monitor agriculture and fisheries mechanisms in greenhouses and create a security system when users are far from the place. There were two modes to choose from: an automatic mode that works based on sensor readings and the set time setting conditions; and a fully manual mode that works on orders from clients via smartphones. Each mode in each prototype model was processed by a microcontroller (NodeMcu). This experiment also developed fuzzy logic on the DHT22 sensor reading (the greenhouse prototype model). This fuzzy method was developed to get the right

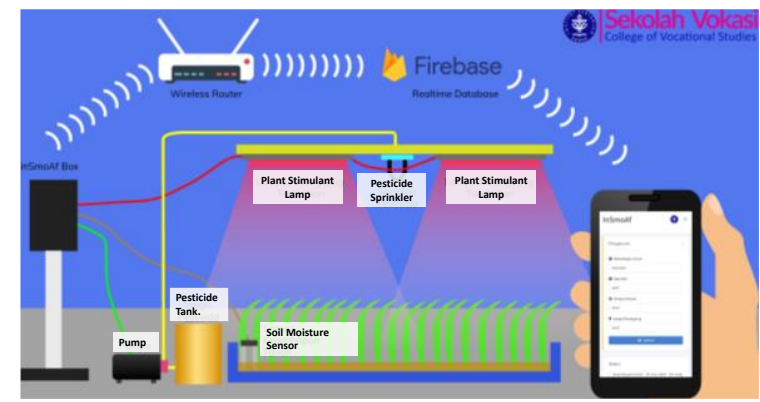

(b)

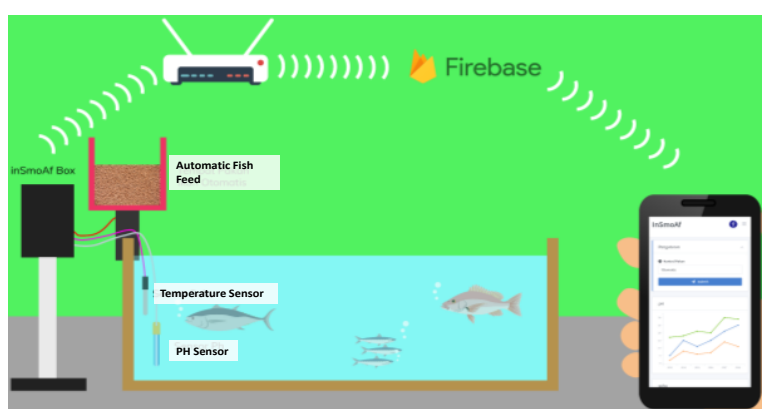

(d)

Figure 1 General inSmoAf on the greenhouse model solution design: (a) model greenhouse; (b) rice field model; (c) hydroponic model; and (d) fish pond model. 


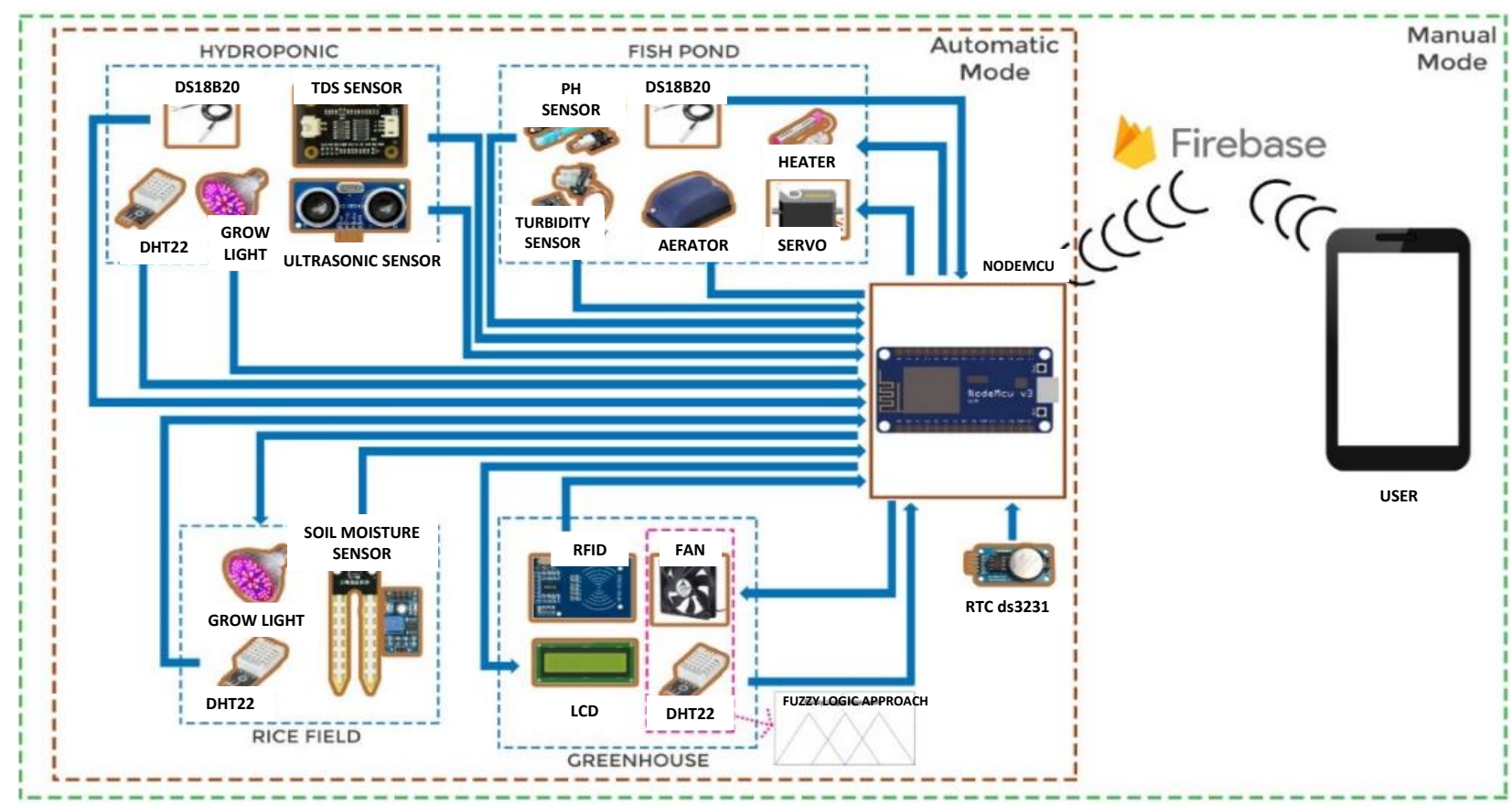

Figure 2 InSmoAf overall system diagram.

temperature and humidity values (each model has an optimum temperature and humidity limit).

\section{Fuzzy Method}

Fuzzy thinking logic is used in the prototype greenhouse to control room temperature and humidity. The sensor then reads the results of the defuzzification to determine the length of time the exhaust fan turns on so that the temperature and room are in ideal conditions. The output variables resulting from the defuzzification results were the temperature and humidity of the greenhouse control room.

Fuzzy logic design was divided into three parts, namely the determination of the membership set, fuzzy rule-based, and the defuzzification process (Maghfiroh et al. 2020; Keykavoussi and Ebrahimi 2018; Ahmad and Moamin 2018; Hu et al. 2019; Zhou et al. 2016; Santosa et al. 2020; Husen et al. 2020; Pourjavad and Shahin 2018). In this work, the fuzzy logic design was used to determine the length of time the exhaust fan works by each treatment's temperature and humidity conditions.

\section{RESULTS AND DISCUSSION}

The following implementation explains the general description of the inSmoAf on the greenhouse model, which is shown in Figure 3. It describes the prototype model of the greenhouse; there are prototype model for rice fields, hydroponic farming, and fish ponds.

The results of the temperature and humidity sensor readings (fuzzy method approach) are used as a control (to activate) the fan; The RTC functions as a control for predefined timing conditions. For example, RTC is used to turn on (17.30-05.30 WIB) and turn off

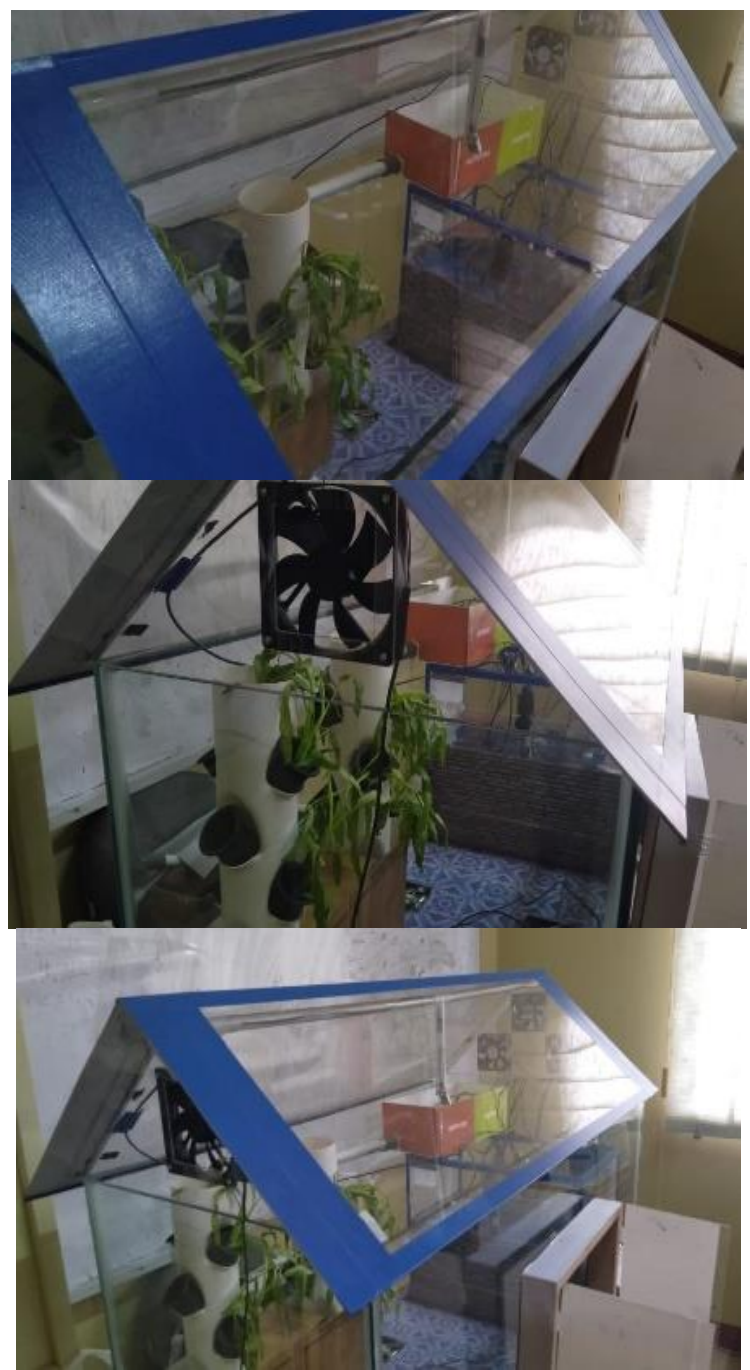

Figure 3 The greenhouse model. 
(05.31-17.29) grow light (rice field and hydroponic models); hexos fan functions as an output that works when getting commands from the reading of the temperature and humidity sensors; and RFID functions as a security for the entrance to the greenhouse. The solenoid (key to the greenhouse door) opens if the RFID card is registered, and the LCDs "Access Granted." If the identity is not registered, the solenoid (key to the greenhouse door) is locked and the LCDs "Access Denied." The access success/failure display is shown in Figure 4.

In the rice field model, the soil moisture sensor reads the dry/wet conditions of the planting medium (35\% for dry conditions, $45.5 \%$ for humid conditions, and $62.2 \%$ for wet conditions) (Kumar et al., n.d.; Balaine et al. 2019); RTC is used to adjust the timing of the on/off the output of the pesticide pump (08.00 and 16.00 hours); and a water pump as an output that works according to the soil moisture sensor readings. The hydroponic farming model is equipped with a vertical hydroponic pipe that functions as a planting medium; RTC functions as a sprinkler timer (07.30 and 16.30); nutrition sensor as a nutrition reading sensor; ultrasonic sensor as water level reading sensor; and two water pumps as output which work according to the readings of the ultrasonic sensor and nutrient sensor. The fish pond model is equipped with a water $\mathrm{pH}$

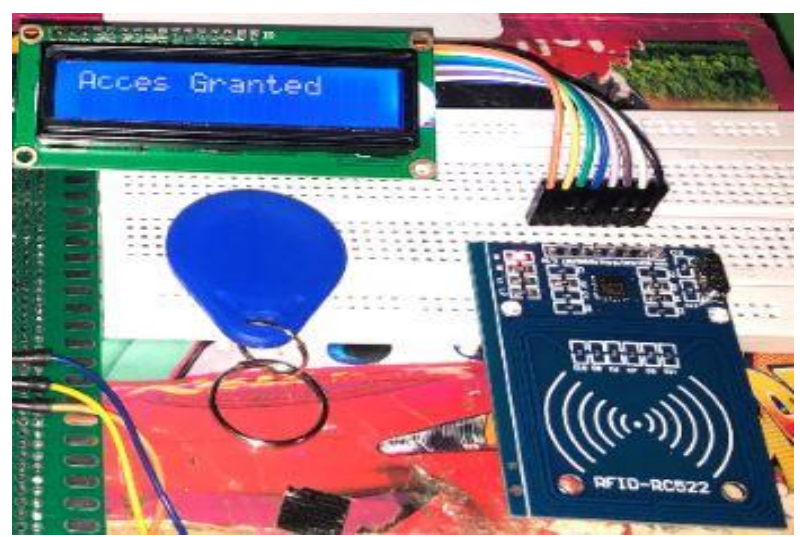

(a)

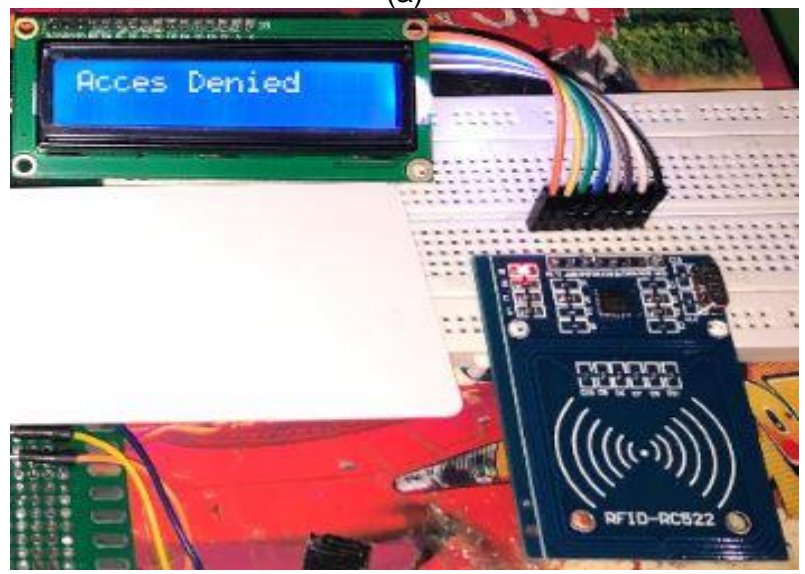

(b)

Figure 4 Display LCD: (a) Access granted and (b) Access denied sensor, oxygen sensor, and water temperature \& humidity sensor, which has their respective functions to read the conditions of $\mathrm{pH}$, oxygen, and water temperature \& humidity in the fish pond; RTC functions as a timer for automatic feeders $(06.00,09.00,12.00$, $15.00,18.00$ ). The frequency of daily fish feeding was done five times, with a time interval of 3 hours and servo as output (motor drive opens/closes the fish feed cover).

\section{Fuzzy Logic Approach}

The trapezoidal type of fuzzy membership set approach is used to control the temperature in the greenhouse by comparing the actual conditions to get the ideal temperature in the greenhouse (MárquezVera et al. 2016). The fuzzy logic consists of two variables from each prototype model, namely variable temperature and variable humidity. The fuzzy logic of the sensor readings is used to process temperature data in the greenhouse to activate the exhaust fan for ideal room conditions (Argo et al. 2019). In this study, to determine the greenhouse's ideal temperature and humidity conditions. We used the temperature and humidity control defuzzification values to determine the length of time the exhaust fan was on. The temperature and humidity membership sets for each treatment were made using the Matlab application. The membership set of the input and output temperature variables of each treatment is shown in Figure 5. At the same time, the membership set of the humidity input and output variables of each treatment is shown in Figure 6.

The membership set of temperature and humidity results produce a fuzzy rule base that applies to each treatment. A fuzzy rule base is used to determine the fuzzy value for temperature and humidity control using the "and" operator. Anfis If Than Else The temperature and humidity control rules are shown in Figure 7.

The results of the fuzzy membership set in Figure 7 show the characteristics of the temperature and humidity variables for each treatment at the greenhouse. The "If Then Else Rule" results are used to determine the temperature and humidity control values through the defuzzification process. The characteristics of the temperature and humidity control "surface of Anfis" are shown in Figure 8.

\section{Automation Module Use Case Analysis}

At this stage, each prototype model has a microcontroller circuit (NodeMCu) equipped with a tool component called RTC (type DS3231). Testing of electronic circuits for RTC was done by uploading a timing program to NodeMCu. The series aims to determine whether the timing of each function is running correctly following the predetermined time. The electronic circuit test results for the RTC are shown in Table 1.

Apart from the RTC, another critical component in the automation module is sensor components. A sensor is an input device that provides an output 


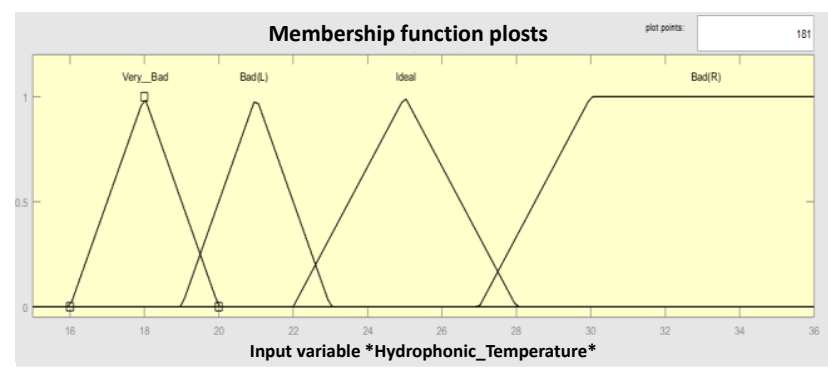

(a)

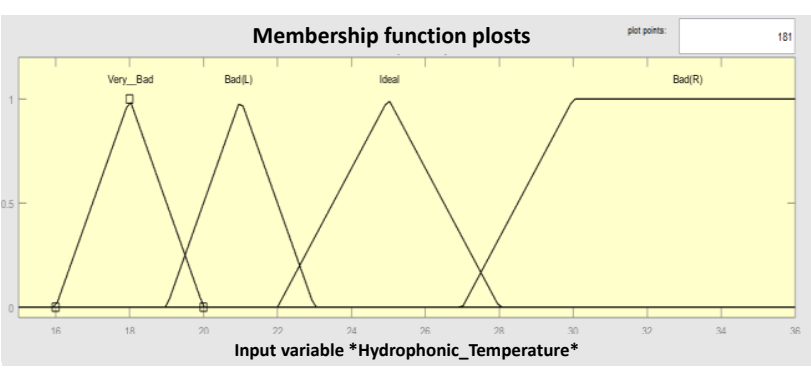

(c)

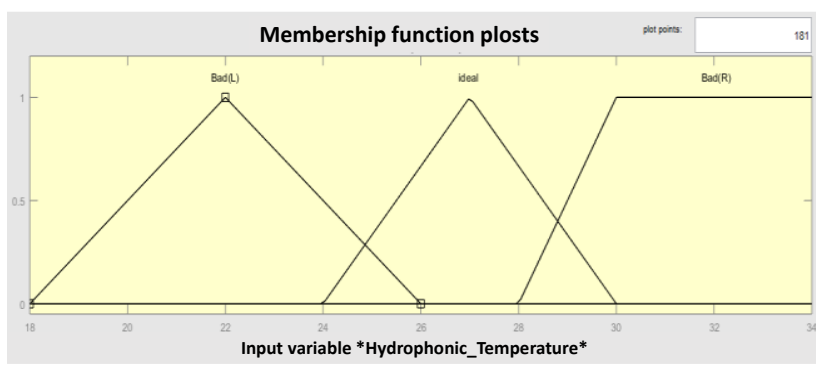

(b)

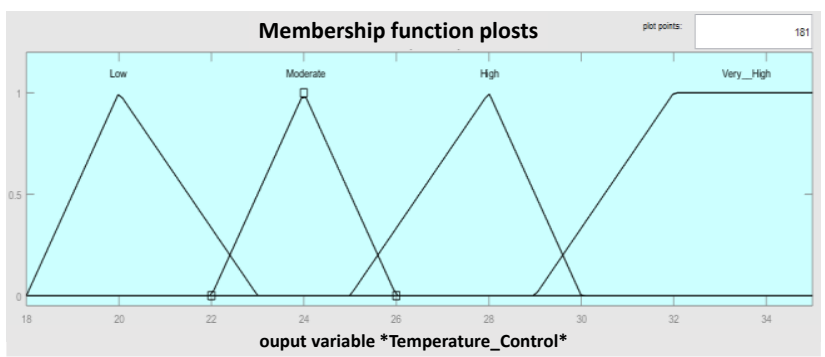

(d)

Figure 5 Membership sets of temperature input and output variables: (a) Rice Field temperature (Input Variable); (b) Hydroponic temperature (Input Variable); (c) Fish Pond temperature (Input Variable); and (d) Temperature control (Variable Output).

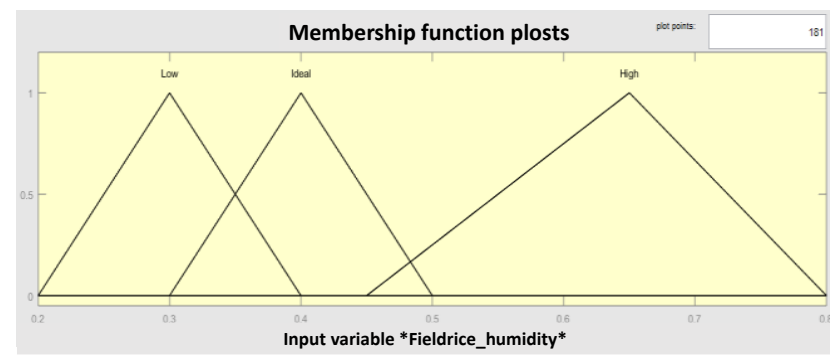

(a)

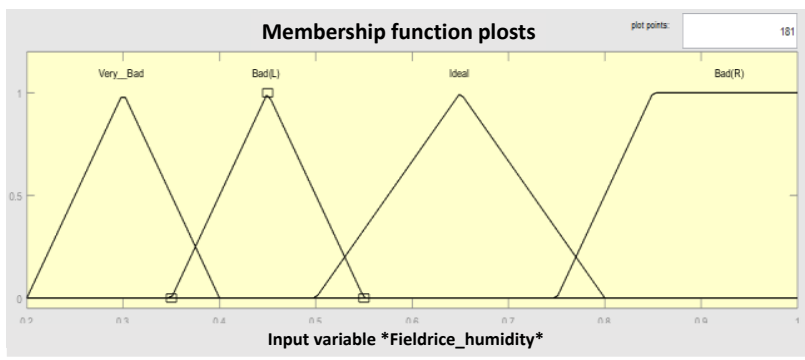

(b)

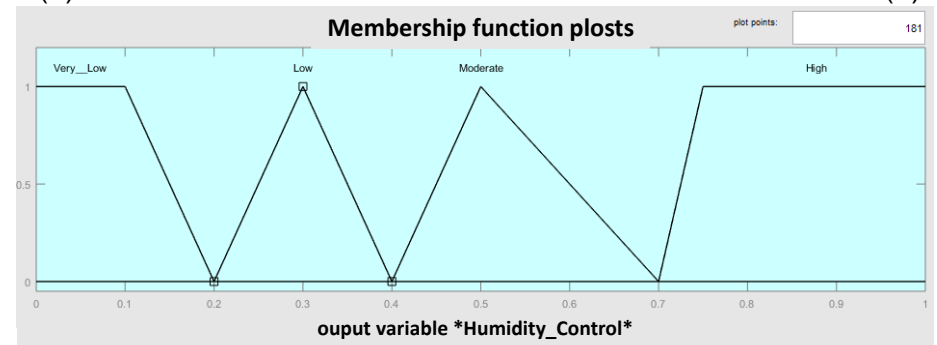

(c)

Figure 6 Membership set of input and output humidity variables: (a) rice field humidity (variable input); (b) hydroponic humidity (variable input); and (c) humidity control (variable output).

(signal) concerning a particular physical quantity (input). The term "input device" in the definition of a sensor is that part of a larger system that provides input to the primary control system (Nasution et al. 2020). The results of testing the fuzzy model on the temperature and humidity output values were used to determine the control conditions of these two variables. Each repetition value was the average result of the sensor readings every 1 minute for 1 hour.
The measurement results of the tool (in each model) against the measurement results of conventional tools (thermometer and hygrometer) have an accuracy of above $95 \%$. Deffuzi (temperature and humidity values) was obtained from the results of the approach using the fuzzy method. The defuzzification value of the output variable was then used as a performance controller for the fan in the greenhouse model prototype. The length of time the fan works was determined from the input of temperature and humidity values from the 


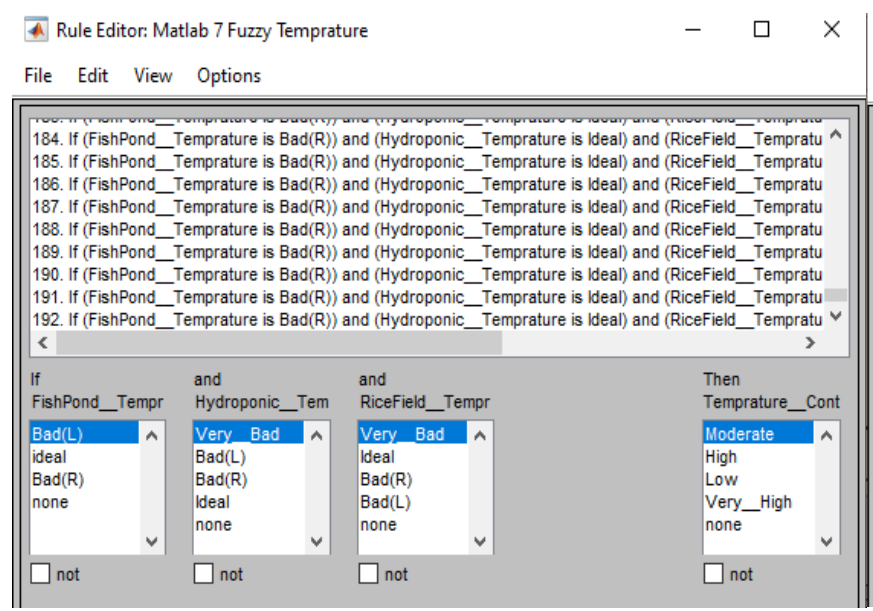

(a)

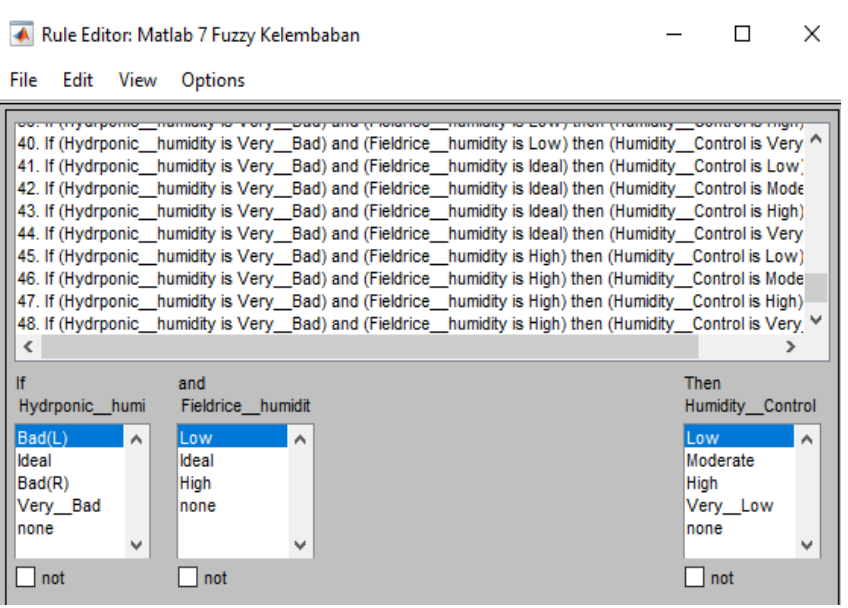

(b)

Figure 7 Anfis if than else rule: (a) Temperature control; (b) Humidity control.

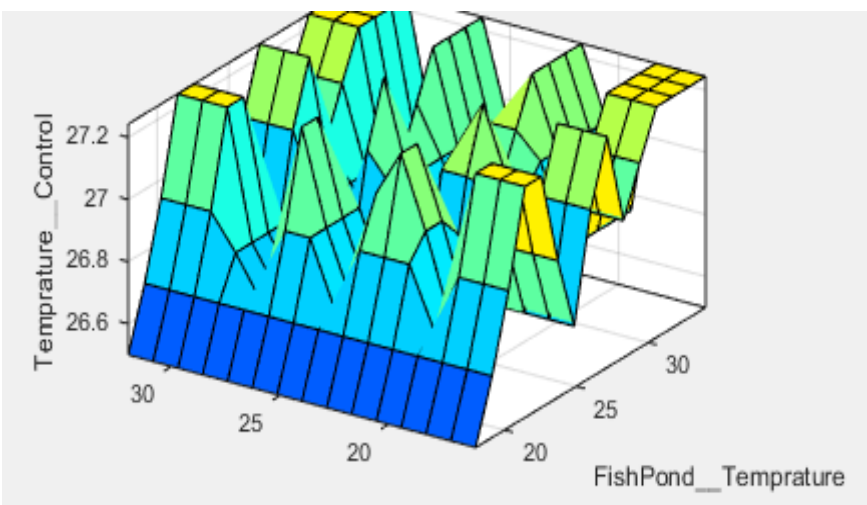

(a)

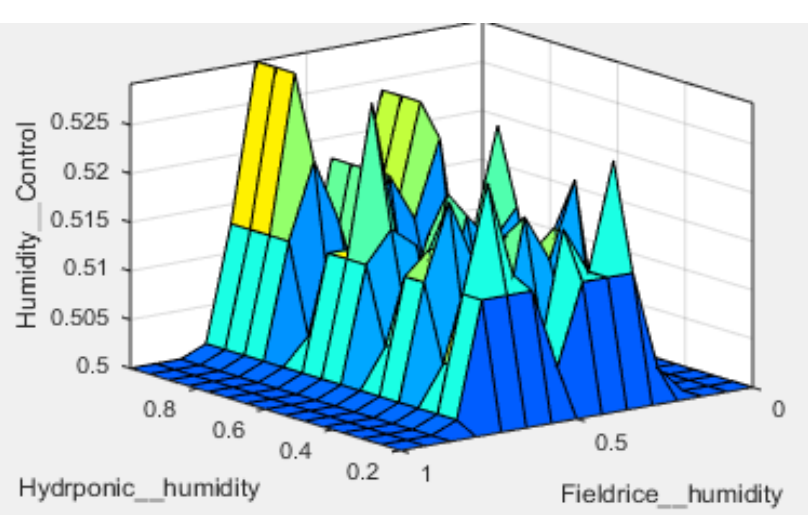

(b)

Figure 8 Surface of anfis controller: (a) Temperature control and (b) Humidity control.

Table 1 Test results for electronic circuits (RTC)

\begin{tabular}{|c|c|c|c|c|}
\hline Used of RTC & $\begin{array}{l}\text { Time } \\
\text { (hour) }\end{array}$ & $\begin{array}{l}\text { Grow Light } \\
\text { Condition }\end{array}$ & $\begin{array}{c}\text { The Grow Light Voltage } \\
\text { Output (volt) }\end{array}$ & Information \\
\hline \multirow{3}{*}{$\begin{array}{l}\text { Greenhouse model } \\
\text { prototype }\end{array}$} & 07.00 & Off & 0.2 & According to Expectations \\
\hline & 18.00 & On & 5.0 & According to Expectations \\
\hline & 04.30 & On & 5.0 & According to Expectations \\
\hline \multirow[t]{4}{*}{ Rice field prototype } & $\begin{array}{l}\text { Time } \\
\text { (hour) }\end{array}$ & $\begin{array}{l}\text { Pesticide Pump } \\
\text { Condition }\end{array}$ & $\begin{array}{l}\text { The Output Voltage of The } \\
\text { Pesticide Pump (volt) }\end{array}$ & Information \\
\hline & 08.00 & Active & 5.0 & According to Expectations \\
\hline & 12.00 & Non-active & 0.2 & According to Expectations \\
\hline & 16.00 & Active & 5.0 & According to Expectations \\
\hline \multirow[t]{4}{*}{$\begin{array}{l}\text { Hydroponic model } \\
\text { prototype }\end{array}$} & $\begin{array}{l}\text { Time } \\
\text { (hour) }\end{array}$ & $\begin{array}{l}\text { Watering Pump } \\
\text { Condirion }\end{array}$ & $\begin{array}{l}\text { The Output Voltage of The } \\
\text { Nutrition Pump (volt) }\end{array}$ & Information \\
\hline & 07.30 & Active & 5.0 & According to Expectations \\
\hline & 12.00 & Non-active & 0.2 & According to Expectations \\
\hline & 16.30 & Active & 5.0 & According to Expectations \\
\hline \multirow[t]{7}{*}{$\begin{array}{l}\text { Fish pond model } \\
\text { prototype }\end{array}$} & $\begin{array}{l}\text { Time } \\
\text { (hour) }\end{array}$ & $\begin{array}{l}\text { Fish Feed Cover } \\
\text { Condition }\end{array}$ & $\begin{array}{l}\text { Servo Voltage Output } \\
\text { (volt) }\end{array}$ & Information \\
\hline & 06.00 & Servo on & 5.0 & According to Expectations \\
\hline & 09.00 & Servo on & 5.0 & According to Expectations \\
\hline & 10.00 & Servo off & 0.2 & According to Expectations \\
\hline & 12.00 & Servo on & 5.0 & According to Expectations \\
\hline & 15.00 & Servo on & 5.0 & According to Expectations \\
\hline & 18.00 & Servo on & 5.0 & According to Expectations \\
\hline
\end{tabular}


defuzzification of the temperature and temperature controls. The fan consisted of 4 pieces that work based on the conditions of the resulting temperature and humidity controls. The light fan $(F)$ rule is shown in Table 2. Based on the light exhaust fan rule, the resulting temperature and humidity are grouped into the normal, high, and very high status to determine the fan that turns on in that condition. The temperature and humidity tests based on the defuzzification value are shown in Table 3. It shows that high temperatures affect the effectiveness of fan performance which is getting longer. Besides, the higher the temperature, the more fans are working ( $>1 \mathrm{fan})$. This is regarding the relationship between exhaust fan conditions based on fuzzy control values.

The value of the soil moisture sensor reading on the rice field prototype model was used to determine the performance of the water pump. Soil is said to be dry if $950<$ soil moisture bit value $\leq 1023$, moist soil if $650<$ soil moisture bit value $\leq 950$ and wet soil if $100<$ soil moisture bit value $\leq 650$ (Siskandar et al. 2020; Latif and Megantoro 2020; Nasution et al. 2020). The water pump releases water if the planting medium (soil) is dry. More specifically, the results of the soil moisture sensor test are shown in Table 4.

The hydroponic model prototype is also equipped with a total dissolved solids (TDS) sensor and an

Table 2 Exhaust fan condition based on fuzzy control value

\begin{tabular}{lccc}
\hline \multirow{2}{*}{ Temperature } & \multicolumn{2}{c}{ Humidity } \\
\cline { 2 - 4 } & Ideal $(\mathrm{HI})$ & High $(\mathrm{HH})$ & Very high $(\mathrm{HVH})$ \\
\hline Ideal $(\mathrm{TI})$ & $\mathrm{Off}$ & $\mathrm{F} 2$ & $\mathrm{~F} 2, \mathrm{~F} 3$ \\
High $(\mathrm{TH})$ & $\mathrm{F} 1$ & $\mathrm{~F} 1, \mathrm{~F} 2$ & $\mathrm{~F} 1, \mathrm{~F} 2, \mathrm{~F} 3$ \\
Very High $(\mathrm{TVH})$ & $\mathrm{F} 1, \mathrm{~F} 2$ & $\mathrm{~F} 1, \mathrm{~F} 2, \mathrm{~F} 3$ & $\mathrm{~F} 1, \mathrm{~F} 2, \mathrm{~F} 3, \mathrm{~F} 4$ \\
\hline
\end{tabular}

Table 3 Exhaust fan control test results against temperature and humidity fuzzy control values (Deffuzy)

\begin{tabular}{|c|c|c|c|c|c|c|c|c|c|c|c|}
\hline \multirow{2}{*}{$\begin{array}{l}\text { Temper } \\
\text { ature } \\
\text { (oc) }\end{array}$} & \multicolumn{3}{|c|}{$\begin{array}{c}\text { Deffuzification } \\
\text { (Control) }\end{array}$} & \multicolumn{2}{|c|}{$\begin{array}{l}\text { Performance } \\
\text { Fan } 1\end{array}$} & \multicolumn{2}{|c|}{$\begin{array}{l}\text { Performance } \\
\text { Fan } 2\end{array}$} & \multicolumn{2}{|c|}{$\begin{array}{l}\text { Performance } \\
\text { Fan } 3\end{array}$} & \multicolumn{2}{|c|}{$\begin{array}{l}\text { Performance } \\
\text { Fan } 4\end{array}$} \\
\hline & Status & $\begin{array}{c}\text { Humidity } \\
(\%)\end{array}$ & Status & $\begin{array}{l}\text { Time } \\
\text { (sec) }\end{array}$ & Condition & $\begin{array}{l}\text { Time } \\
\text { (sec) }\end{array}$ & Condition & $\begin{array}{l}\text { Time } \\
\text { (sec) }\end{array}$ & Condition & $\begin{array}{l}\text { Time } \\
\text { (sec) }\end{array}$ & Condition \\
\hline 26.7 & Ideal & 50.5 & Ideal & & Off & & Off & & Off & - & Off \\
\hline 26.9 & Ideal & 51.1 & Ideal & & Off & & Off & & Off & - & Off \\
\hline 26.7 & Ideal & 51.6 & High & & Off & 180 & On & & Off & - & Off \\
\hline 27.0 & High & 51.1 & Ideal & 60 & On & & Off & & Off & - & Off \\
\hline 26.9 & Ideal & 51.9 & High & & Off & 190 & On & & Off & - & Off \\
\hline 27.5 & Very High & 51.7 & High & 30 & On & 186 & On & 14 & On & - & Off \\
\hline 26.9 & Ideal & 53.1 & Very High & & Off & 190 & On & 34 & On & - & Off \\
\hline 26.9 & Ideal & 50.8 & Ideal & & Off & & Off & & Off & - & Off \\
\hline 27.0 & High & 51.4 & High & 60 & On & 176 & On & & Off & - & Off \\
\hline 27.1 & High & 50.6 & Ideal & 62 & On & & Off & & Off & - & Off \\
\hline
\end{tabular}

Table 4 Moisture sensor test results against water pump

\begin{tabular}{ccccc}
\hline Repeat to & Soil type & $\begin{array}{c}\text { Soil moisture sensor } \\
\text { value (bit) }\end{array}$ & $\begin{array}{c}\text { Value of output voltage } \\
\text { (volts) }\end{array}$ & Water pump \\
\hline 1 & \multirow{3}{*}{ Wet } & 150 & 0.7 & Turn off \\
2 & & 256 & 1.2 & Turn off \\
3 & \multirow{3}{*}{ Moist } & 560 & 2.7 & Turn off \\
\hline 1 & & 683 & 3.3 & Light up \\
Light up \\
3 & & 693 & 3.3 & Light up \\
\hline 1 & \multirow{2}{*}{ Dry } & 718 & 3.4 & Light up \\
2 & & 950 & 4.6 & Light up \\
3 & & 1014 & 4.9 & Light up \\
\hline
\end{tabular}


of 6.5-8.5. This range is the optimum range for fish health. Stabilizing the $\mathrm{pH}$ condition of the fish pond lime is usually given if the $\mathrm{pH}$ is too acidic, on the contrary, if the $\mathrm{pH}$ is too alkaline, fermentation is given/add ketapang leaves (Sung et al. 2017). The value of water turbidity in fish ponds also significantly affects fish health. The value of water turbidity in a good fish pond is not more than $50 \mathrm{NTU}$. If the water is too dirty, fish farmers usually do the filter, sediment, or change the water (Mccoy et al. 2017). In this study, the $\mathrm{pH}$ conditions and water turbidity conditions in the pond were set in the range of values $6.5-8.5$ for $\mathrm{pH}$ and not more than 50 NTU for the water turbidity. It is found that the value of the tool's accuracy for the $\mathrm{pH}$ sensor and the turbidity sensor is $97.3 \%$ and $99.0 \%$, meaning that that the tool are successful.

\section{Smartphone Module Use Case Analysis}

In this study, smartphones were used to change automatic mode to manual mode (control by smartphone) or vice versa through an application system anytime and anywhere. Manual mode is activated if the automatic mode is not activated. Automatic mode reactivates if manual mode via apps is turned off. Figure 9 (a) shows the display changing from automatic to manual mode on the smartphone application. Figure 9(b) shows the condition of NodeMCU connected to the access point. When the system is in manual mode, the RTC and sensors will not function because the complete control of the greenhouse system is with the client. The test results show that the system is entirely manual when NodeMCU is connected to the access point. IP server, which shows that it is connected, is 192.168.43.118.

\section{CONCLUSION}

The design of loT and Al on control and automation system devices: inSmoAf (Integrated Smart Modern Agriculture and Fisheries) on The Greenhouse has been successfully constructed for rice field farming

Table 5 Total dissolved solids (TDS) sensor test results and ultrasonic sensor of pump

\begin{tabular}{cccc}
\hline $\begin{array}{c}\text { Sensor value TDS } \\
(\mathrm{ppm})\end{array}$ & $\begin{array}{c}\text { Sensor value } \\
\text { ultrasonic }(\mathrm{cm})\end{array}$ & $\begin{array}{c}\text { Selenoid valve, nutrient } \\
\text { container }\end{array}$ & Selenoid valve fish pond \\
\hline 1021 & 5.0 & Open & Open \\
1270 & 10.0 & Open & Closed \\
1560 & 15.0 & Closed & Closed \\
1440 & 5.0 & Closed & Open \\
\hline
\end{tabular}

Table 6 Test results of $\mathrm{pH}$ and turbidity sensors against selenoid valve

\begin{tabular}{ccccc}
\hline Hour & $\begin{array}{c}\mathrm{pH} \\
\text { Sensor Tool }\end{array}$ & Digital Water pH & $\begin{array}{c}\text { Turbidity Sensor Tool } \\
\text { (NTU) }\end{array}$ & $\begin{array}{c}\text { Turbidity Meter } \\
\text { SGZ200BS (NTU) }\end{array}$ \\
\hline 09.00 & 6.9 & 6.7 & 48.0 & 48.5 \\
12.00 & 6.8 & 6.8 & 48.0 & 49.2 \\
15.00 & 6.7 & 6.6 & 49.0 & 49.5 \\
18.00 & 6.7 & 6.5 & 45.0 & 46.3 \\
21.00 & 7.1 & 6.9 & 40.0 & 39.7 \\
00.00 & 7.2 & 6.9 & 38.0 & 37.9 \\
03.00 & 7.2 & 6.9 & 37.0 & 37.3 \\
06.00 & 6.9 & 6.7 & 44.0 & 44.3 \\
\hline
\end{tabular}

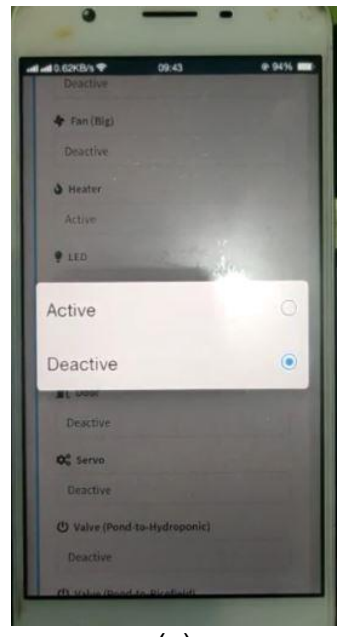

(a)

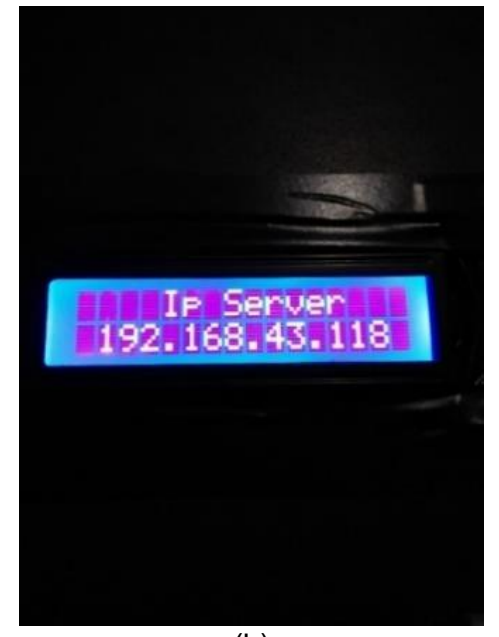

(b)

Figure 9 (a) Display changing inSmoAf system mode on smartphone application and (b) IP display condition of NodeMCU connected to access point. 
models, hydroponic farming models, and fish pond models using automatic mode and manual mode. Manual mode is activated if the automatic mode is not activated. Automatic mode reactivates if manual mode via the app is turned off. The test results show that the system is entirely in manual mode when the NodeMCU is connected to the access point. The server ip that shows it is connected is 192.168.43.118. The fuzzy approach was successfully carried out until the "ideal," "high," and "very high" conditions of temperature and humidity were obtained. This condition provides information to the microcontroller to activate which exhaust fan should turn on. The radio frequency identification (RFID) system for greenhouse doors (solenoids) can open if the RFID card ID is registered. However, if the RFID card ID is not registered, the door (solenoid) remains closed. The relationship between the TDS sensor data reading and the ultrasonic sensor to the Water pump activation has worked as expected. The pump releases water when the planting medium (soil) is dry. The water quality data measured by the system is in the value range of $6.5-8.5$ for $\mathrm{pH}$ and not more than 50 NTU for water turbidity.

\section{ACKNOWLEDGEMENTS}

We gratefully the funding from Program Penelitian Hibah Bersaing Sekolah Vokasi Institut Pertanian Bogor under contract no. 10225/IT3.S3/KS/2020.

\section{REFERENCES}

Altamirano M, Ana, Pérez JS, Muñoz P, Gabarrell X. 2020. Analysis of Urban Agriculture Solid Waste in the Frame of Circular Economy: Case Study of Tomato Crop in Integrated Rooftop Greenhouse. Science of The Total Environment. 139375. https://doi.org/10.1016/j.scitotenv.2020.139375.

Benyezza $\mathrm{H}$, Bouhedda M, Zerhouni MC, Boudjemaa M, Dura SA. 2018. Fuzzy Greenhouse Temperature and Humidity Control Based Arduino. International Conference on Applied Smart Systems (ICASS). 16. doi: 10.1109/ICASS.2018.8652017.

Borstel, Von FD, Suárez J, De E, Joaquín R, Borstel FDV, Rosa ED. 2013. Feature Article Feeding and Water Monitoring Robot in Aquaculture Greenhouse. Industrial Robot: An International Journal. 40(1): 10-19. https://doi.org/10.1108/ 01439911311294219.

Chaudhary DD, Nayse SP, Waghmare LM 2011. Application of Wireless Sensor Networks for Greenhouse Parameter Control in Precision Agriculture. International Journal of Wireless \& Mobile Networks (IJWMN). 3(1): 140-49.

Cobantoro, Fajaryanto A, Setyawan MB, and Wibowo
MAB. 2019. Otomasi Greenhouse Berbasis Mikrokomputer Raspberry PI. Jurnal IImiah Teknologi Informasi Asia. 13(2): 115. https:// doi.org/10.32815/jitika.v13i2.360.

El-madbouly, Essam, Ibrahim A, Hameed. 2017. "Reconfigurable Adaptive Fuzzy Fault-Hiding Control for Greenhouse Climate Control System Mohamed I, Abdo. International Journal of Automation and Control. 11(2): 164-87.

Ferentinos, Katsoulas KPN, Tzounis A, Kittas C, Bartzanas T. 2015. A Climate Control Methodology Based on Wireless Sensor Networks in Greenhouses. Innovation and New Technologies in Protected Cropping. 75-82. https://doi.org/ 10.17660/ActaHortic.2015.1107.9.

Ghani, Saud, Bakochristou F, Ali EM, Bialy AE, Gamaledin SMA, Rashwan M, Abdelhalim AM, Ismail SM. 2019. Design Challenges of Agricultural Greenhouses in Hot and Arid Environments - A Review. Engineering in Agriculture, Environment and Food. 12(1): 48-70. https://doi.org/ 10.1016/j.eaef.2018.09.004.

Gourdo L, Fatnassi H, Tiskatine R, Wifaya A, Demrati H, Aharoune A, Bouirden L. 2019. Solar Energy Storing Rock-Bed to Heat an Agricultural Greenhouse. Energy. 169(1): 206-212. https:// doi.org/10.1016/j.energy.2018.12.036.

Gregoryan, Moses, Andjarwirawan J, Lim R. 2019. Sistem Kontrol Dan Monitoring Ph Air Serta Kepekatan Nutrisi Pada Budidaya Hidroponik Jenis Sayur Dengan Teknik Deep Flow Techcnique. Jurnal Infra. 7(2): 1-6.

Gruening MAC, Goded I, Seufert G, Cescatti A. 2016. Agriculture, Ecosystems and Environment Water Management Reduces Greenhouse Gas Emissions in a Mediterranean Rice Paddy Fi Eld. Agriculture, Ecosystems and Environment. 1-11. https:// doi.org/10.1016/j.agee.2016.08.017.

Haris, Abdul, Kusuma DT, Pratama RN. 2018. Sistem Penyortiran Buah Apel Manalagi Menggunakan Sensor. Jurnal PETIR. 11(1): 92-95.

Hu, Guangji, Bakhtavar E, Hewage K, Mohseni M, Sadiq R. 2019. Heavy Metals Risk Assessment in Drinking Water: An Integrated Probabilistic-Fuzzy Approach. Journal of Environmental Management 250(1): 109514. https://doi.org/10.1016/j.jenvman. 2019.109514.

Humaerah, Dwi A. 2013. Budidaya Padi (Oryza Sativa) dalam Wadah dengan. Jurnal Agribisnis. 7(2): 199210.

Keykavoussi, Ashkan, Ebrahimi A. 2018. Total Quality Management \& Business Excellence Using Fuzzy Cost - Time Profile for Effective Implementation of Lean Programmes; SAIPA Automotive Manufacturer, Case Study. Total Quality 
Management. 0(0): 1-25. https://doi.org/10.1080/ 14783363.2018.1490639.

Kuncoro, Hari P, Wijaya K. 2019. Serang Kabupaten Purbalingga terhadap Teknologi Screen-House dan Sistem Hidroponik untuk Memperkuat Budidaya Strawberry. Jurnal Pengabdian Kepada Masyarakat 3(1): 28-33.

Kusuma A, Darlis D, Novianti A. 2019. Implementation of Smart Garden Watering on Dormitory Garden of Telkom University Using Ethernet Module On Raspberry $\mathrm{Pi}$ Based on loT. E-Proceeding of Applied Science. 5(3): 2902-2911.

Lamprinos, llias, Charalambides $M$, Chouchoulis $M$. 2015. Greenhouse Monitoring System Based on a Wireless Sensor Network. Conference Proceedings Paper - Sensors and Applications, no. 2: 1-6. https://doi.org/10.3390/ecsa-2-E009.

Latif A, Megantoro P. 2020. The Prototype of Automatic Water Sprinkle with Soil Moisture Sensor Based on ATMega 8535. Journal of Physics: Conference Series. 1464(1). https://doi.org/10.1088/17426596/1464/1/012035.

Maghfiroh, Hari, Hermanu C, Ibrahim MH, Anwar M, Ramelan A. 2020. Hybrid Fuzzy-PID like Optimal Control to Reduce Energy Consumption. Telkomnika (Telecommunication Computing Electronics and Control). 18(4): 2053-2061. https:// doi.org/10.12928/TELKOMNIKA.V18I4.14535.

Marzuki, Imam, Wicaksono I. 2019. Rancang Bangun Sistem Pemantauan Dan Kontrol Otomatis Pada Greenhouse Berbasis Wireless Sensor Network (WSN). Program Studi Teknik Elektro Fakultas Teknik Universitas Panca Marga. 4(2): 1-5.

Mccoy, Daniel, Mcmanus MA, Hi A, Young C, Andrea BD, Ruttenberg KC, Alegado A. 2017. Large-Scale Climatic Effects on Traditional Hawaiian Fishpond Aquaculture. PLOS ONE. 1-17.

Meili, Liu, Yankang B. 2018. Embedded Automatic Control System for Temperature, Humidity and Light Intensity in Agricultural Greenhouses. In Proceedings of the 2nd International Symposium on Computer Science and Intelligent Control (ISCSIC '18). Association for Computing Machinery, New York, $14.1-5$. https://doi.org/10.1145/ 3284557.3284742

Miranda, Jhonattan, Ponce $\mathrm{P}$, Molina A, Wright P. 2019. Computers in Industry Sensing, Smart and Sustainable Technologies for Agri-Food 4. Computers in Industry. 108(1): 21-36. https:// doi.org/10.1016/j.compind.2019.02.002.

Nasution IS, Iskandar MR, Jayanti DS. 2020. Internet of Things: Automatic Sprinklers in Prototyping Greenhouse Using Smartphone Based Android. IOP Conference Series: Earth and Environmental Science. 425(1). https://doi.org/10.1088/1755-

\section{5/425/1/012069}

Pitakphongmetha J, Boonnam N, Wongkoon S, Horanont T, Somkiadcharoen D, Prapakornpilai J. 2016. Internet of things for planting in smart farm hydroponics style. IEEE Explore. 1-5. http://doi.org/10.1109/ICSEC.2016.7859872

Pourjavad, Ehsan, Shahin A. 2018. The Application of Mamdani Fuzzy Inference System in Evaluating Green Supply Chain Management Performance. International Journal of Fuzzy Systems. 20(3): 90112. https://doi.org/10.1007/s40815-017-0378-y.

Rahayu, Nina, Utami WS, Razabi MM. 2018. Rancang Bangun Sistem Kontrol dan Pemantauan Aquaponic Berbasis loT pada Kelurahan Kutajaya. ICIT Journal. 4(2): 192-201. https://doi.org/ 10.33050/icit.v4i2.93.

Rahmawati, Diana. 2019. Pengujian Monitoring OnLine Rumah Kaca Cerdas Berbasis Android. Cyclotron. 2(1). https://doi.org/10.30651/ cl.v2i1.2529.

Santosa SH, Irawan S, Ardani I. 2020. Determination of Overall Equipment Effectiveness Superflex Machine Using Fuzzy Approach. 4(2). https://doi.org/10.29099/ijair.v4i2.142.

Santosa SH, Suhendar S, Hidayat AP, and Ardani I. 2020. Fuzzy Logic Approach to Determine the Optimum Nugget Production Capacity. Jurnal IImiah Teknik Industri. 19(1): 70-83. https:// doi.org/10.23917/jiti.v19i1.10295.

Saraswathi D, Manibharathy $\mathrm{P}$, Gokulnath $\mathrm{R}$, Sureshkumar E, Karthikeyan K. 2011. Automation of Hydroponics Green House Farming Using IOT. IEEE, no. 1997: 1-4.

Siregar, Baihaqi, Efendi, Sahrul, Pranoto, Heru, Ginting, Roy, Andayani, Ulfi, Fahmi. 2017. Remote monitoring system for hydroponic planting media. 1-6. 10.1109/ICTSS.2017.8288884.

Siskandar R, Kusumah BR. 2019. Design and Construction of Control Devices for Aquaponic Monitoring Management. Aquacultura Indonesiana, 20(2): 72-79. https://doi.org/10.21534/ai.v20i2.151

Siskandar R, Fadhil MA, Kusumah BR. 2020. Internet Of Things : Automatic Plant Watering System. 9(4): 297-310.

Sujadi H, Nurhidayat Y. 2019. Smart Greenhouse Monitoring System Based on Computer Science | Industrial Engineering | Mechanic Engineering | Civil Engineering Computer Science | Industrial Engineering | Mechanic Engineering | Civil Engineering. Jurnal J-Ensitec. 6(1): 371-377.

Sung, Wen-tsai, Chen J, Hsiao SJ. 2017. "Fish Pond Culture via Fuzzy and Self-Adaptive Data Fusion Application." IEEE International Conference on Systems, Man, and Cybernetics (SMC). 2986- 
2991.

Sutikno, Khotib M. 2019. Prototipe Sistem Kontrol Parameter Fisik (Suhu-Kadar Air TanahKelembaban Udara) Pada Green House Untuk Budidaya Tanaman Cabai. 1(2): 86-92. https:// doi.org/10.32528/elkom.v1i2.3087.

Syah ANA, Nuryawati T, Litananda WS. 2018. "Pengembangan Smart Greenhouse Untuk Budidaya Holtikultura." Seminar Nasional PERTETA 2018, no. 2010: 1-10.

Vera $M$, Marco A, Julio C, Fernández R, Natale LFC, Lafont $F$, Balmat JF, Jorge I, Esparza-Villanueva. 2016. Temperature Control in a MISO Greenhouse by Inverting Its Fuzzy Model. Computers and Electronics in Agriculture 124: 168-74. https:// doi.org/10.1016/j.compag.2016.04.005.

Xu J, Dai F, Xu Y, Yao C, Li C. 2019. Wireless Power Supply Technology for Uniform Magnetic Field of Intelligent Greenhouse Sensors. Computers and Electronics in Agriculture. 156. https://doi.org/ 10.1016/j.compag.2018.11.014.

Zhou Q, Wu W, Liu D, Li K, Qiao Q. 2016. Estimation of Corrosion Failure Likelihood of Oil and Gas Pipeline Based on Fuzzy Logic Approach. Engineering Failure Analysis. 70: 48-55. https:// doi.org/10.1016/j.engfailanal.2016.07.014. 